\title{
Analysing the Impact of GST on Tax Revenue in India: The Tax Buoyancy Approach
}

\footnotetext{
Submitted 30/08/19, $1^{\text {st }}$ revision 20/09/19, $2^{\text {nd }}$ revision 15/10/19, accepted 25/11/19

\section{Udai Lal Paliwal ${ }^{1}$, Nitin Kishore Saxena ${ }^{2}$ Ashutosh Pandey ${ }^{3}$}

\begin{abstract}
:
Purpose: The purpose of this paper is to analyse the impact of newly introduced Goods and Services Tax (GST) on tax revenue in India. This paper adopts the tax buoyancy approach for analysing the impact of GST on tax revenue.

Design/Methodology/Approach: We conducted our study using semi logarithmic ANCOVA regression model in which we introduced Value Added Tax (VAT) and GST as dummy variables.
\end{abstract}

Findings: Our study finds that after the introduction of GST India's tax revenue has become less responsive to the changes in GDP. It indicates that post introduction of GST there is some reduction in the tax burden on the consumers and corporates which supports the government's justification behind the introduction of GST.

Practical Implications: The study is expected to help the government in deciding the future course of action towards effective policy making for revenue generation.

Originality/Value: Since none of the existing studies analyses the impact of GST on tax revenue our study is unique and fulfils the gap in the existing literature.
}

Keywords: Goods and Services Tax, GST, Tax Buoyancy, VAT

JEL Codes: H2O, H27, H3O

Article Type: Research study.

\footnotetext{
${ }^{1}$ Professor \& Dean, Institute of Commerce, Nirma University, Ahmedabad (India),

Corresponding author: udai@nirmauni.ac.in

${ }^{2}$ Assistant Professor, Institute of Commerce, Nirma University, Ahmedabad (India), nitin.saxena@nirmauni.ac.in

${ }^{3}$ Assistant Professor, Institute of Commerce, Nirma University, Ahmedabad (India) ashutosh.pandey@nirmauni.ac.in
} 


\section{Introduction}

After long marathon meetings and debates, the government of India has implemented Goods and Services Tax (GST) in the country on July 1, 2017 (IBEF, 2017). For this moment, the entire nation was waiting for decades. It is the biggest tax reform in India since Independence. The motive behind implementation of the GST is the concept of "one nation, one market, one tax" in the country. The Prime Minister of India, Mr. Modi characterized GST as "The Good and Simple Tax". The main aim of GST is to remove the complexity of the preceding tax regime and develop an easy to implement tax system in the country. Almost, all the leading countries of the world have a uniform tax collection system. This uniform tax system was much needed to attract foreign investment in India. In this competitive world, we need a tax system like GST in the country not only to motivate the leading business firms to come to India for business but also help local industry to work under a uniform system of taxation. GST system has developed one single window for all the business units to obtain multi-state registrations, interpretation of provisions, determining the place of supply, transitional issues, etc.

The GST bill has merged more than ten types of indirect taxes into one tax and collected at one place for state and central government. In the previous structure, at each point of sale, additional taxes were applied to the tax value of each good and service in the country. (Wiencek, 2017). The GST rollout, with a single stroke, has converted India into a unified market of more than 1.3 billion citizens, dismantling all the inter-state barriers with respect to trade (Cleartax, 2018). In the previous tax system, we used to pay a "tax on tax" on every purchase that was made throughout the value chain. It increases the cost (Kotak, 2019) of the product by roughly 25$30 \%$. GST has not only changed this pattern but also created an easy platform to claim the input tax credit (ITC) to claim back the paid tax amount and easily adjust the accounts.

The introduction of the new indirect tax system with new and unique concepts was not an easy task especially in the country like India, wherein each state has its own tax system along with central taxes (Jain, 2018). Though before the implementation of GST, Government and all the nodal agencies considered all the aspects, which they may face after implementing GST, there were not only teething problems such as technical challenges some economists also raised concerns about its possible adverse in pact on businesses in short run. Former governor of Reserve Bank of India (RBI) Dr. Rajan said that demonetisation and GST are the two major headwinds that held back India's economic growth (Rajan, 2018). GST was supposed to replace the complex indirect tax system prevalent in the country with easier, uniform tax system (Vishav, 2018). However, in a country like India, where government gets more than $60 \%$ of its earning from the indirect taxes, may be it was difficult to implement a single tax rate. India is one of the few countries with five tax slabs $(0 \%, 5 \%, 12 \%, 18 \%$ and 28\%) (Das, 2018). Subramanian (2018) agreed in 
principle to come up with less number of tax slabs, however, due to varied needs of a diverse economy like India, Government had to adopt multiple tax slabs.

\subsection{GST Rates in India}

Essential services and food items have been placed in the lower tax brackets, while luxury services and products have been placed in the higher tax bracket. Government exempted the regular consumption foods like fresh fruits and vegetables, milk, buttermilk, curd, natural honey, flour, bread, etc., from GST for the benefit of masses. Over 1300 goods and 500 services have beeen classified under four tax slabs of 5\%,12\%, 18\% and 28\% (Figure 1). GST on gold has been kept at $3 \%$ and rough precious, diamonds and semi-precious stones is placed at a special rate of $0.25 \%$ (Kotak, 2019).

Figure 1. GST rates in India

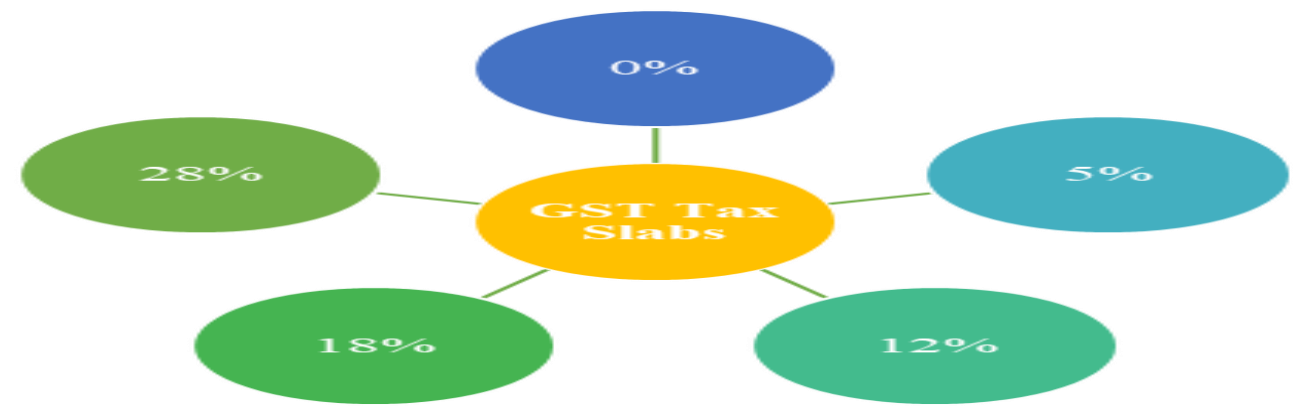

\subsection{Objective of the Research}

The main objective of this paper is to analyse the impact of GST on tax revenue. We analyse the trends of tax buoyancy, direct tax buoyancy and indirect tax buoyancy during pre and post implementation of GST. We hypothesize that post implementation of GST, tax revenue has become more responsive to the changes in the GDP.

\subsection{GST Collection Pattern in India:}

Figure 2 shows the pattern of GST collection in India from July 2017 to June 2019. During the last two years the average tax collection of the government was around Rs. 96,025 Crore per month. During this period maximum tax collection was recorded in the month of April, 2019 of Rs. 1,13,865 Crore and lowest in the month of November 2017 of Rs. 83,780 Crore. The average growth in GST collection during the last twenty-four months was around $0.49 \%$. Year on year average growth of $6.6 \%$ was recorded in the last quarter (April to June) of 2019 compared with the same quarter a year ago. 
Figure 2. Pattern of GST Collection in India July 2017-Jun 2019 (Rs. Crore)

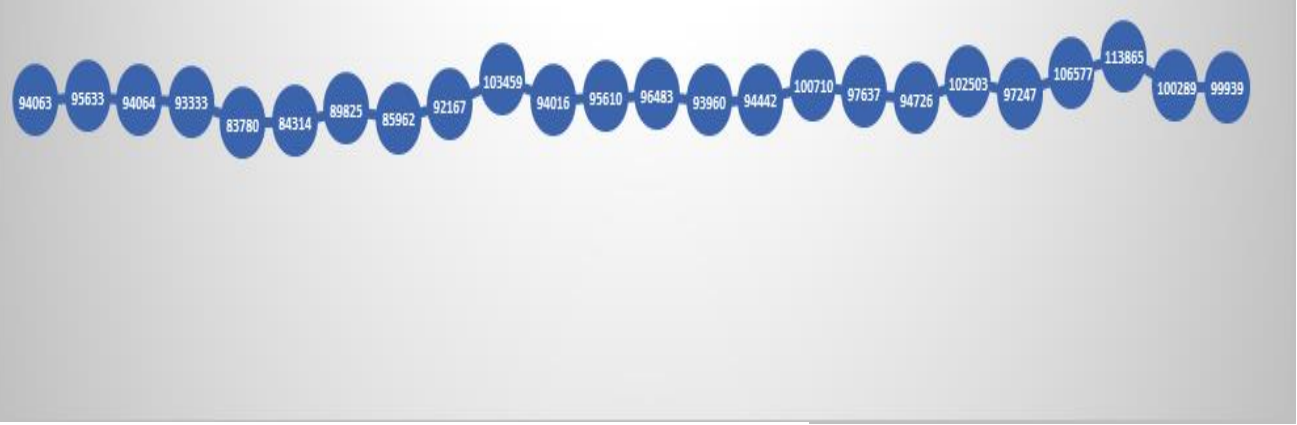

Source: Various Reports of the Press Information Bureau.

\section{Literature Review}

The moto of implementation of GST is to improve the economic growth, create a simple indirect tax system and to increase tax revenue of the government largely by removing various obstacles that the financial system has (Roychowdhury, 2012). Changes in the Indirect tax system is a major challenge because indirect tax is a major source of income for centre as well as states. In India, states are earning approximately 60 to 65 per cent of state's own tax revenue (SOTR) from indirect taxes. Tax collection largely depends on the nature and growth of the tax base but also on the improved effort of the tax collection (Dwivedi \& Sinha, 2017).In 2005, GOI initiated VAT (Value Added Tax) with the consultation of the states to reduce the double taxation, multiplicity of rates, tax competition between states and central agencies (Nepram, 2011).

Tax reforms must cover the aspects like sufficient revenue to deal with long-run challenges, encourage long-run economic growth, and provide progressivity in the face of increasing inequality in the system (Seidman, 2013). GST is expected to improve the efficiency and simplicity in the indirect tax system (Freebairn, 2011). This type of tax reforms helpful for the developing countries to reduce the trade tax liabilities and helps to promote the business entities in the country (Emran \& Stiglitz, 2005). Single tax system helpful for the increase the valuation of the business and it also helps to improve the logistic performance of the trade (Fernando and Chukai, 2018).

Analysis of tax buoyancy is important as it helps in the formulation and design of appropriate tax policy as it explains the role of tax revenue in ensuring the long run fiscal sustainability (Dudine, 2018). A number of studies have been conducted for 
studying the elasticity of tax revenue in both the developed and developing economies around the world using the tax buoyancy approach. Girouard and Andre (2005), and Belinga and others (2014) used the tax buoyancy approach for estimating the revenue elasticities for OECD countries. Similarly, Upender (2008) in his study studied the degree of tax buoyancy in India during pre and post-tax reform period and concluded that the tax buoyancy, which was just above one during pre tax reform period, is less than one during post tax reform period. There exists a gap in the existing literature on the study of impact of GST on tax revenue using the tax buoyancy approach. Our study fulfils this gap in existing literature and finds the impact of GST on the tax revenue using tax buoyancy approach of analysis.

\section{Methodology and Model}

With the objective of studying the impact of GST on the tax revenue we did literature review and arrived at the important variables for this study. We analysed the tax buoyancy for the period 1980-81 to 2017-18 using the following model:

$$
B=\frac{\frac{T R_{t}-T R_{t-1}}{T R_{t-1}}}{\frac{Y_{t}-Y_{t-1}}{Y_{t-1}}}
$$

where, $t=$ time and TR= Total Revenue and $\mathrm{Y}=$ Gross Domestic Product.

Tax buoyancy is one of the effective tool for the assessment of the effectiveness of any tax system in terms of its mobilization capacity. It is an indicator to measure efficiency in revenue mobilization in response to growth in GDP. It is related with the expansion of tax base in the country. If tax buoyancy is high, it indicates builtin-flexibility in the tax structure.

Further, if it is greater than one, it indicates more than proportionate response of the tax revenue to rise in GDP, and if it is less than one, it indicates less than proportionate response of the tax revenue to rise in GDP. The tax buoyancy tends to generally vary from year to year, thus it is useful to measure buoyancy over a longer period. The relation among the identified variables were established and tested using semi logarithmic ANCOVA regression. In a semi logarithmic regression model the dependent and explanatory variables are in logarithmic terms while we do not take natural log of dummy variables (Gujarati, 2009). A semi logarithmic ANCOVA regression model can be written as:

$$
\ln Y=\beta_{0}+\beta_{1} \ln X+\beta_{2}
$$


where, $\ln Y$ is the natural $\log$ arithm of the variable tax revenue, $\ln X$ is the natural logarithm of the variable GDP, $D$ is the dummy variable which shows the introduction of GST or VAT in India.

We estimate the model using the method of ordinary least squares (OLS). The estimated coefficient $\beta_{1}$ shows the change in tax revenue due to a change in GDP. Thus we can say that $\beta_{1}$ shows tax buoyancy. We checked for the presence of autocorrelation using Durbin-Watson test and by analyzing the autocorrelation function $(\mathrm{ACF})$ and the partial autocorrelation function (PACF).

\section{Data Description and Sources}

To measure the impact of the introduction of GST on the total tax revenue, we took total tax revenue of the government of India as the dependent variable. We obtained the total tax revenue data for the period 1980-2018 form the Budget documents of the Government of India. We obtained the Gross Domestic Product (GDP) data from RBI handbook of statistics on Indian economy. Since total tax revenue is dependent on Gross domestic product, we took GDP as the explanatory variable. The other explanatory variables which we incorporated in our analysis are VAT, GST and VATGST. Description of each data variable is given in Table 1 and summary of the statistics is presented in Table 2 .

Table 1. Description of Data Variables

\begin{tabular}{|c|c|}
\hline Variable & Description \\
\hline TR & Total Tax Revenue of the Government of India measured in rupees billion \\
\hline GDP & Gross Domestic Product of India measured in measured in rupees billion \\
\hline VAT & $\begin{array}{l}\text { It is the dummy variable representing the Value Added Tax. It takes value } 0 \\
\text { in the period before the year } 2005 \text { and } 1 \text { in the period 2005-2016 and } 02017 \\
\text { onwards. }\end{array}$ \\
\hline GST & $\begin{array}{l}\text { It is the dummy variable representing the Goods and Services Tax. It takes } \\
\text { value } 0 \text { in the period before the year } 2017 \text { and } 1 \text { in the period } 2017 \text { onwards }\end{array}$ \\
\hline VATGST & $\begin{array}{l}\text { It is the interaction term between the variable VAT and GST. It takes the } \\
\text { value } 0 \text { in the period before } 2005 \text { and } 1 \text { in the period } 2005 \text { onwards. }\end{array}$ \\
\hline
\end{tabular}

Table 2. Summary Statistics

\begin{tabular}{|l|l|l|}
\hline & GDP $($ Rs Billion & TR (Rs Billion) \\
\hline Mean & 42473.76 & 4516.088 \\
\hline Median & 18366.58 & 1717.520 \\
\hline Maximum & 190101.6 & 22712.42 \\
\hline Minimum & 1382.200 & 131.4900 \\
\hline Std. Dev. & 52865.39 & 5894.516 \\
\hline Skewness & 1.407446 & 1.597296 \\
\hline Kurtosis & 3.820455 & 4.644171 \\
\hline Jarque-Bera & 13.96974 & 20.97667 \\
\hline Probability & 0.000926 & 0.000028 \\
\hline
\end{tabular}




\begin{tabular}{|l|l|l|}
\hline Sum & 1656476. & 176127.5 \\
\hline Sum Sq. Dev. & $1.06 \mathrm{E}+11$ & $1.32 \mathrm{E}+09$ \\
\hline Observations & 39 & 39 \\
\hline
\end{tabular}

Source: Author's Calculation based on data obtained from budget documents and RBI Handbook of Statistics.

On the basis of the methodology discussed in the preceding section we estimated two models given below:

$\ln T R=\beta_{0}+\beta_{1} \ln G D P+\beta_{2} V A T$

$\ln T R=\beta_{0}+\beta_{1} \ln G D P+\beta_{2} V A T+\beta_{3} V A T G S T$

where $\ln T R$ is the natural logarithm of the total tax revenue, $\ln G D P$ is the natural logarithm of the gross domestic product, VAT is the dummy variable which captures the change in tax revenue due to the introduction of VAT., VATGST shows the interaction of VAT and GST.

Since in equation $4 \beta_{3}$ coefficient captures the change in tax revenue due to both VAT and GST on comparing the coefficients of equation 3 and 4 we can find the impact of GST on tax revenue. We estimated the equations in Eviews. The estimated results have been summarized in Table 3 .

Table 3. Summary of the Regression Results

Dependent Variable: TR

\begin{tabular}{l|ll}
\hline \multirow{4}{*}{ Intercept } & Model 1 & Model 2 \\
& $-2.30^{* * *}$ & $-1.99^{* * *}$ \\
VAP & $(0.00)$ & $(0.00)$ \\
& $1.00^{* * *}$ & $0.96^{* * *}$ \\
$V A T G S T$ & $(0.00)$ & $(0.00)$ \\
& 0.03 & $-0.13^{* * *}$ \\
& $(0.34)$ & $(0.01)$ \\
Observations & Not included in model & $0.26^{* * *}$ \\
R-squared & & $(0.00)$ \\
Source: Author' & 39 & 39 \\
& 0.99 & 0.99
\end{tabular}

Source: Author's Calculation based on the data obtained from budget documents and RBI Handbook of Statistics.

The estimated models have a high R-squared value of 0.99 which shows that both the models are a good fit. We found the coefficient of GDP, which shows tax buoyancy, is positive and highly significant in both the models. Tax buoyancy in first model is 1 which shows that before introduction of GST there is proportionate response in tax revenue to the change in GDP. However, tax buoyancy in second model is 0.96 which means that after the introduction of GST there is less than 
proportionate response in tax revenue to the change in GDP. Thus we can say that after the introduction of GST India's tax revenue has become less responsive to the changes in GDP. It also indicates that the post introduction of GST there is some reduction in the tax burden on the consumers and corporates which supports the government's justification behind the introduction of GST.

The estimated coefficient of VAT in the first model is not significant which means that VAT was not having any significant impact on the tax revenue of the government. We further extended our first model and included an interaction variable of VAT and GST. The negative coefficient of VAT shows that the introduction of VAT resulted into some reduction in tax revenue. The coefficient of the interaction variable of VAT and GST is significant and positive which means that after the introduction of GST the variable VATGST leads to an increase in the tax revenue.

To further support our analysis, we calculate tax buoyancy in India for the period $1981-82$ to $2018-19$. We observe a reduction in tax buoyancy from 1.26 in 2016-17 to 1.19 in $2017-18$. Thus we can conclude that the with the introduction of GST in the year 2016-17 tax buoyancy has fallen consequently the tax revenue has become less responsive to the changes in the GDP.

Figure 3. Tax Buoyancy in India during 1981-82 to 2018-19

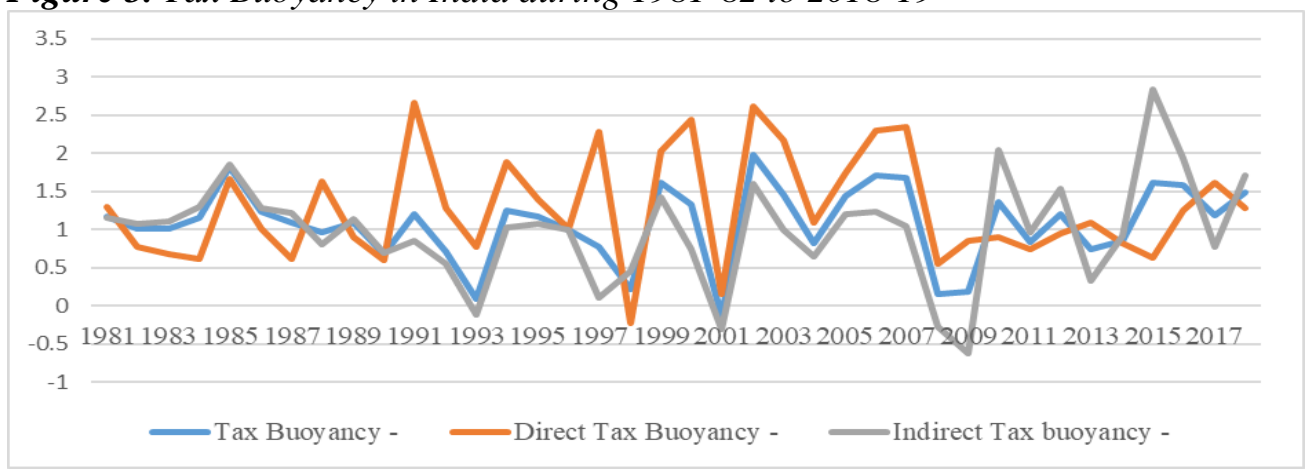

Source: Budget Documents of Government of India and author's calculation.

\section{Conclusion and Recommendations}

With the objective of analysing the impact of the introduction of GST on tax revenue in India we conducted a regression analysis. In our study we found that after the introduction of GST the tax revenue has become less responsive to the changes in GDP. The results contradict our hypothesis that tax revenue has become more responsive to the changes in GDP. The results of our study have wide policy implications given the current economic situations in the country. The growth of GDP in India in the year 2018-19 has averaged around 6.8 percent while the GDP growth rate in the first quarter of 2019-20 has reduced to 5 percent. Given the 
current slowdown in GDP if the government tries to increase the growth by increasing the public expenditure hoping that the consequent increase in income would raise sufficient tax revenue which would prevent the fiscal deterioration in the long run. However, since tax revenue has become less responsive, it implies that the economy would not be able to mobilise sufficient revenue through taxation to the same extent as the increase in public expenditure. It can have adverse implications on the fiscal sustainability in the long run if no appropriate policy measures are taken.

\section{References:}

Belinga, V., Benedek, D., Mooij, R., Norregaard, J. 2014. Tax Buoyancy in OECD Countries. IMF Working Paper 110.

Breen, J., Bergin-Seers, S., Roberts, I., Sims, R. 2002. The Impact of the Introduction of the GST on Small Business In Australia. Asian Review of Accounting.

Choon, L.S., Osman, A., Muhammad, S., Yeng, S.K., Jin, L.Y. 2016. Goods and Services Tax (GST) Compliance among Malaysian Consumers: The Influence of Price, Government Subsidies and Income Inequality. Procedia Economics and Finance, 198-205.

Cleartax. 2018. Impact of GST on the Indian Economy. Retrieved from https://cleartax.in/s/impact-of-gst-on-indian-economy

Das, D. 2019. GST Pass-through Across Indian Sates: Evidence from Difference-inDifferences. The Indian Economic Journal.

Das, K. 2018. Decoded: Why India's GST has multiple tax slabs? Retrieved from https://www.timesnownews.com: https://www.timesnownews.com/businesseconomy/economy/article/decoded-why-india-s-gst-has-multiple-tax-slabs/247658

Dudine, P. 2018. How buoyant is the tax system? New evidence from a large heterogeneous panel. Journal of International Development, 30(6), 961-991.

Dwivedi, H.K., Sinha, S.K. 2017. Trends in Collection of Value Added Tax in West Bengal: A Commentary. South Asian Journal of Marcoenonics and Public Finance, 5(2), 238-248.

Emran, M.S., Stiglitz, J.E. 2005. On selective indirect tax reform in developing countries. Journal of Public Economics, 599-623.

Fernando, Y., Chukai, C. 2018. Value Co-Creation, Goods and Service Tax (GST) Impacts on Sustainable Logistic Performance. Research in Transportation Business \& Management, 92-102.

Freebairn, J. 2011. A Better and Larger GST? The Economic and Labour Relations Review.

Girouard, N., Andre, C. 2005. Measuring Cyclically-Adjusted Budget Balances for the OECD Countries. OECD Economics Department Working Papers, 434.

Gujarati, D. 2009. Basic Econometrics. Tata McGraw-Hill Education.

IBEF. 2017. Goods \& Services Tax (GST). Retrieved 9 10, 2019, from India Brand Equity Foundation: https://www.ibef.org/research/india-study/goods-and-services-tax

Jain, P. 2018. 365 days of GST: A historic journey. Retrieved from www.pwc.in: https://www.pwc.in/tax-and-regulatory-services/indirect-tax/365-days-of-the-gst-ahistoric-journey/article.html

K.M. 2017. Business Line. Retrieved from https://www.thehindubusinessline.com: https://www.thehindubusinessline.com/economy/tax-buoyancy-improves-thanks-toindirect-levy/article9466851.ece\# 
Kotak. 2019. GST rate slabs simplified. Retrieved from https://www.kotak.com/en/stories-infocus/gst-rate-slabs.html: https://www.kotak.com/en/stories-in-focus/gst-rateslabs.html

Nepram, D. 2011. State-Level Value Added Tax and Its Revenue Implications in India: A Panel Data Analysis. Margin: The Journal of Applied Economic Research, 5(2), 245-265.

Rajan, R. 2018. India's economic growth held back due to note ban, GST: Raghuram Rajan. Retrieved from https://economictimes.indiatimes.com: https://economictimes.indiatimes.com/news/economy/policy/indias-economicgrowth-held-back-due-to-demonetisation-gst-raghuramrajan/articleshow/66567451.cms

Roychowdhury, P. 2012. Vat And Gst In India - A Note. Paradigm, 80-87.

Seidman, L. 2013. Overcoming the Fiscal Trilemma with Two Progressive Consumption Tax Supplements. Public Finance Review, 41(6), 824-851.

Subramanian, A. 2018. A Market Unified. Finance \& Development, 40-41.

Vishav. 2018. One year of GST: Long way to go for a simple, uniform tax regime. Retrieved from https://www.thenewsminute.com:

https://www.thenewsminute.com/article/one-year-gst-long-way-go-simple-uniformtax-regime- 83880

Wiencek, E.V. 2017. The Effect of the GST on Indian Growth. Washington: Board of Governors of the Federal Reserve System. 